\title{
Seasonal variations of the chemical composition of Brazilian propolis
}

\author{
Vassya Bankova ${ }^{a}$, Gergana Boudourova-Krasteva ${ }^{a}$, \\ Simeon Popov ${ }^{a *}$, Jose M. Sforcin ${ }^{b}$, Silvia R. Cunha Funari ${ }^{b}$

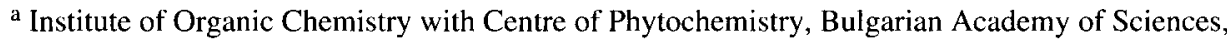 \\ 1113 Sofia, Bulgaria \\ ${ }^{\mathrm{b}}$ Depto. Microbiologia e imunologia, Instituto de Biociencias, UNESP 18618-000 Botucatu, SP, \\ Brazil
}

(Received 10 October 1997; accepted 15 January 1998)

\begin{abstract}
The seasonal variations in the chemical composition of Brazilian propolis, collected by two bee subspecies, Africanized Apis mellifera and European Apis mellifera ligustica, have been investigated by GC and GC-MS. The main components of the samples were phenolic compounds, especially cinnamic acid derivatives, the only exception being the autumn sample from Apis mellifera ligustica, where diterpenes predominated. In propolis from both subspecies, diterpenes appeared in summer and reached maximum percentage in autumn, but were absent during the other seasons. The results obtained indicated that both bee subspecies collect propolis from among the same group of plants, and that there are at least two important plant sources, but these remain unidentified. (C) Inra/DIB/AGIB/Elsevier, Paris
\end{abstract}

propolis / chemical composition /phenolics / diterpenes / GC-MS / Brazil / seasonal variation

\section{INTRODUCTION}

In the temperate zone of the Northern Hemisphere bees collect propolis only in summer (including late spring and early autumn: about 4 months) [6] and thus inves- tigations on the seasonal variations of propolis composition are meaningless in these regions. In Brazil, the propolis collection proceeds throughout the entire year, so some seasonal variations are possible but in the literature there are no data concerning this

* Correspondence and reprints

E-mail: iochnp@bgcict.acad.bg 
subject. These variations are important for the practical application of propolis: it could be harvested when there is the highest concentration of biologically active compounds. Also, the chemical composition and its seasonal variations can provide information about the plant sources of propolis. This knowledge could provide a possibility for increasing the yields of propolis by modification of the forestry around the hives. It is also of importance for the future development of a standardization procedure for Brazilian propolis. Samples collected by Africanized bees and European bees (Apis mellifera L.) were investigated in order to find out if these two subspecies collect propolis with similar chemical composition and with seasonal variations.

\section{MATERIALS AND METHODS}

\subsection{Propolis}

Propolis was harvested in the Bee Keeping Section of the School of Veterinary Medicine and Animal Husbandry of Botucatu, UNESP. Propolis samples were obtained from colonies of Africanized honeybees and European honeybees (Apis mellifera L.) and collected throughout the year from plastic nets. After each month, nets were taken and frozen to promote propolis [11]. Samples were pooled according to the four seasons.

\subsection{Extraction of propolis}

Propolis, cut into small pieces, was extracted with $70 \%$ ethanol (twice, for $24 \mathrm{~h}$ ). The alcohol was evaporated and the residue dried to obtain the balsam. The percentage of the extracted matter was as follows: Asp (A. mellifera Africanized, spring) $44.6 \%$, Asu (A. mellifera Africanized, summer) $37.0 \%$, Aa (A. mellifera Africanized, autumn) $36.0 \%$, Aw (A. mellifera Africanized, winter) $49.2 \%$, Isp (A. mellifera, spring) $46.5 \%$, Isu (A. mellifera, summer) $32.3 \%$, Ia (A. mellifera, autumn) $33.5 \%$, Iw (A. mellifera, winter) $32.0 \%$.

\subsection{Sample preparation for GC and GC-MS}

A $2.5 \mathrm{mg}$ sample of the alcohol extract was dissolved in $20 \mu \mathrm{L}$ dry pyridine, $30 \mu \mathrm{L} \mathrm{N}, \mathrm{O}-$ bis(trimethylsilyl)trifluoroacetamide (BSTFA) were added and the mixture heated at $80^{\circ} \mathrm{C}$ for $20 \mathrm{~min}$ in a screw-cap vial. The sample was diluted with $100 \mu \mathrm{L}$ dry pyridine and analysed by GC and GC-MS.

\subsection{Gas-chromatography}

A $25 \mathrm{~m} \times 0.25 \mathrm{~mm}$ I.D. fused silica capillary column with SPB-1 as stationary phase was used. The linear velocity of the carrier gas (nitrogen) was $0.01 \mathrm{~cm} . \mathrm{s}^{-1}$ and the splitting ratio was $1: 30$. The column temperature was programmed from 100 to $150^{\circ} \mathrm{C}$ at $5 \mathrm{deg} \cdot \mathrm{min}^{-1}$, then from 150 to $280^{\circ} \mathrm{C}$ at $3 \mathrm{deg} \cdot \mathrm{min}^{-1}$, with a $20 \mathrm{~min}$ hold at 280 ${ }^{\circ} \mathrm{C}$. A flame ionization detector was used at 300 ${ }^{\circ} \mathrm{C}$, injector temperature was $300{ }^{\circ} \mathrm{C}$.

\subsection{Gas chromatography-mass spectrometry}

For the GC-MS analysis a $30 \mathrm{~m}$ SPB-1 fused silica capillary column was used in a HP 5890 gas chromatograph with a HP 5972 MSD detector. The samples were introduced via an all-glass injector working in the split mode, with $\mathrm{He}$ as a carrier gas and a temperature programme $100-300 \mathrm{deg} \cdot \mathrm{min}^{-1}$ at $5 \mathrm{deg} \cdot \mathrm{min}^{-1}$.

\subsection{Identification of compounds}

The identification was accomplished using computer searches on commercial libraries. In some cases, when identical spectra were not found, only the structural type of the corresponding component was proposed on the basis of its mass-spectrum. Reference compounds were co-chromatographed where possible to confirm $\mathrm{GC}$ retention times.

\section{RESULTS AND DISCUSSION}

Alcoholic extracts prepared with $70 \%$ EtOH (balsam) are assumed to contain almost all biologically active propolis constituents and for this reason are commonly 
used in practice [6]. Seasonal changes observed in the amounts of alcohol-soluble substances are given in the Materials and methods section.

Most of the components of the balsam possess low volatility and for this reason the total alcoholic extracts have been silylated and investigated by GC and GC-MS. The results are summarized in table $I$. The quantitation is based on GC data.

From the results obtained it is evident that samples investigated differ considerably from bee glue in temperate zones, where Populus species are the main propolis source (in Europe, North America, Mongolia and even New Zealand $[2,8,7,12]$. For temperate zone propolis, the typical poplar bud phenolics are characteristic: mainly flavonoids, accompanied by smaller amounts of phenolic acids and their esters. Our samples differed also from tropical propolis from Venezuela [10] in which prenylated benzophenones, originating from Clusia flower exudates, were the main components.

In Brazil there are no poplars and thus the chemical composition of Brazilian propolis has to be different. Both bee subspecies investigated produce propolis with similar chemical composition (table I). In all samples we found aromatic acids (dihydrocinnamic, $p$-coumaric, ferulic and caffeic acids) which are common for poplar propolis, as well as 3-prenyl-p-coumaric acid and 3,5-diprenyl-p-coumaric acid, found earlier in Brazilian propolis [1] and 2,2dimethyl-6-carboxyethenyl-8-prenyl-2Hbenzopyran, recently identified in Brazilian propolis [5]. Only three flavonoids were present in the investigated samples: kaempferid, which was found in European [9] and in Brazilian propolis [3]; 5,6,7-trihydroxy3,4'-dimethoxyflavanone and aromadendrin4'-methyl ether, both isolated recently from Brazilian propolis [5]. All the above-mentioned phenolic compounds were present in all the samples investigated, their concentrations showing some seasonal variations.
Phenolics in the investigated samples were accompanied by some terpenoid compounds. However, their presence seemed to be connected with the change of seasons. A diterpenic acid appeared in the summer samples; in autumn samples its concentration increased and a second compound of this type appeared. The mass spectra of these substances are characteristic for labdane type diterpenes and one $(\mathrm{RT}=35.80)$ was identified tentatively as imbricatoloic acid, isolated recently from Brazilian propolis [4], while the other $(\mathrm{RT}=36.55)$ could be didehydroimbricatoloic acid or its isomer. Till now, labdane type diterpenic acids have been found only in Brazilian propolis and their probable source are Araucaria species |4|. In the samples collected by Apis mellifera ligustica in autumn and winter two triterpenic alcohols were present. Their mass spectra are similar to these of amyrine type triterpenoids, but additional amounts of these compounds must be isolated in order to identify them.

The sample Ia deserves special attention. Unlike all other samples investigated, phenolics are not the main components of this sample. Instead, diterpenic acids predominate.

There are other polar compounds in investigated propolis samples, but their low concentrations and/or the overlapping of the gas-chromatographic peaks did not allow their quantitation. They are mainly aromatic acids - benzoic acid and its derivatives ( $p$-methoxybenzoic acid, $p$-hydroxybenzoic acid, vanillinic acid), cinnamic acid, hydroxydihydrocinnamic acid and ferulic acid. Some of their esters were also identified - ethyl dihydrocinnamate and benzyl cinnamate. Carbonyl compounds such as vanillin and hydroquinone were identified.

As it is evident from table $I$, there are seasonal differences in the chemical composition of propolis samples harvested under standardized conditions. The decrease in some biologically active components, such as phenolic acids, is accompanied by the 


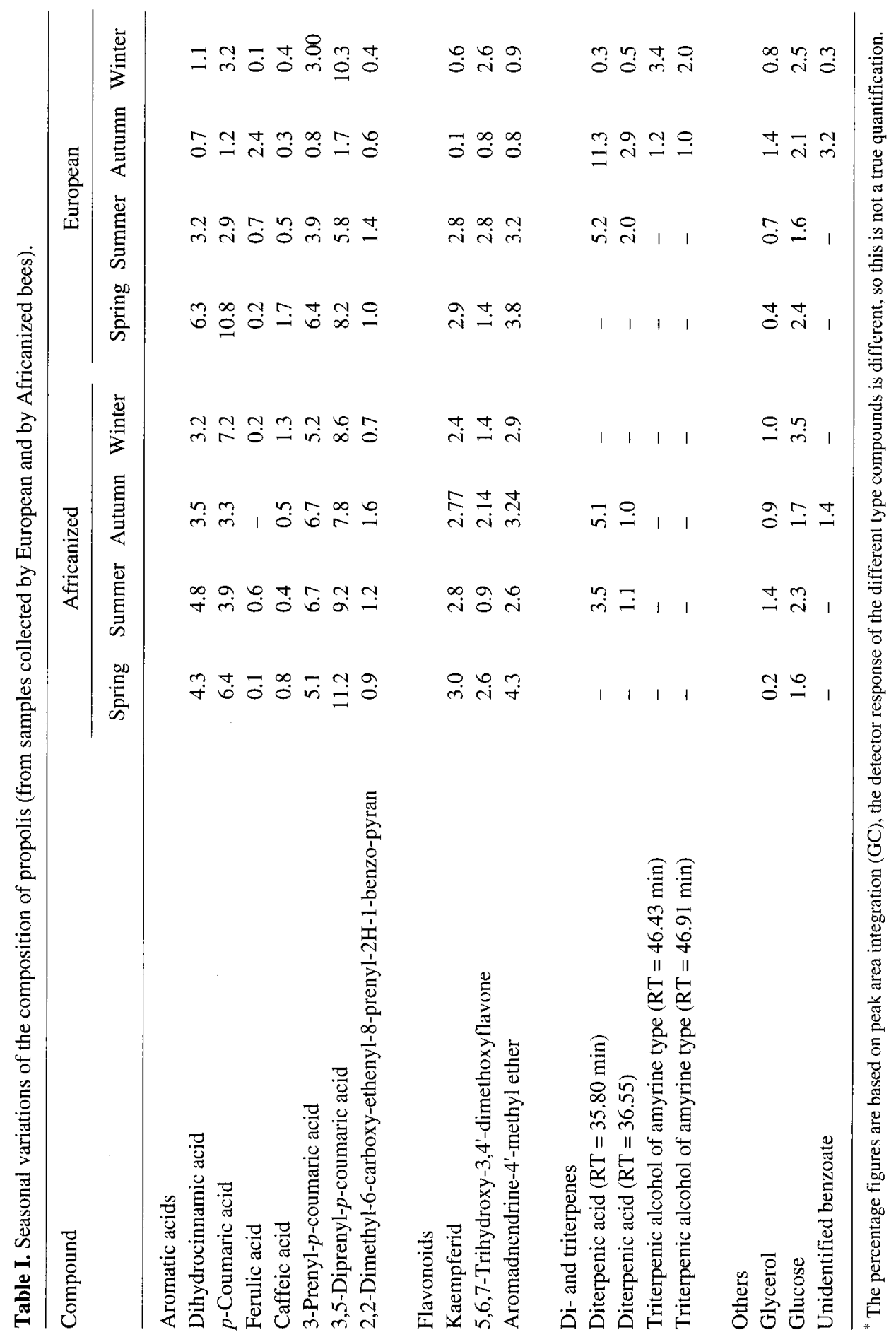


increase in other biologically active components, for example diterpenic acids, and we could expect that some of the biological activities, due to these compounds, e.g. antibacterial, antifungal, etc., will be similar in different seasons. The bee subspecies also appeared to have some influence on the propolis quantitative composition.

The data obtained about the chemical composition of Brazilian propolis and seasonal variations of its main constituents gave useful information about the plant origin of the investigated propolis samples. Evidently, both subspecies use one and the same pool of plant sources but bees from different subspecies prefer certain specific ones among them in certain seasons. Reviewing table I, and especially the differences between $\mathbf{I a}$, Aa and all other samples, the hypothesis could be proposed that there are two main plant sources of the investigated propolis samples - one of them produces $p$-coumaric acid, prenylated $p$-coumaric acids, dihydrocinnamic acid, aromadendrine-4'-methyl ether and kaempferid.

A second important plant source could donate both diterpenic acids and an unidentified ester of benzoic acid with a dihydroxysesquiterpenoid. Small amounts of triterpenic alcohols were found only in propolis from Apis mellifera ligustica, which is an indication that these bees collect small amounts of propolis from some third plant. The above-discussed differences in the composition of sample Ia are an indication that in autumn Apis mellifera ligustica collects propolis mainly from the second plant, while Apis mellifera (Africanized) collects smaller amounts of propolis from it. In general, it seems that the second source is easily available or preferred in autumn.

Contrary to propolis from the temperate zones, where poplars are its sole source, according to our results in Brazil there are more plants that bees could accept as sources of propolis and in different regions its chemical composition can differ. However, the criteria for choice of propolis plant sources by bees remain unclear.
On the basis of the results obtained and literature data about tropical plants, we could propose some of the possible plant sources of the propolis samples (Baccharis species, Araucaria species) that we investigated, but further investigation is needed on resin producing plants from the vicinity of the hives.

\section{ACKNOWLEDGEMENTS}

The authors wish to thank Miss N. Nikolova for technical assistance with GC. Partial financial support from the Universidade Estadual Paulista, Botucatu, Post-Graduate Course, is gratefully acknowledged.

\section{Résumé - Variation saisonnière de la} composition chimique de la propolis brésilienne. Dans les régions à climat tempéré les abeilles ne récoltent la propolis que l'été. $\mathrm{Au}$ Brésil, la récolte à lieu toute l'année. Nous avons étudié les variations saisonnières de la composition chimique de la propolis récoltée au Brésil par les abeilles africanisées (Apis mellifera L.) et les abeilles européennes, Apis mellifera ligustica à l'aide de la chromatographie en phase gazeuse (CG) et de la CG couplée à la spectrographie de masse. La composition differe significativement de celle de la propolis européenne en raison de l'origine botanique différente. Dans les échantillons étudiés les principales substances étaient des composés phénolés, le plus souvent des dérivés de l'acide cinnamique. La seule exception est l'échantillon récolté par les abeilles européennes en automne, dans lequel les acides diterpéniques prédominent. Dans la propolis récoltée par les deux races les diterpènes apparaissent l'été et atteignent leur maximum à l'automne, mais ils sont absents aux autres saisons. Comme le montre le tableau $I$, la diminution quantitative de certains composés biologiquement actifs, comme les acides phénoliques, s'accompagne d'une augmentation quantitative d'autres composés biologiquement actifs, tels que les acides diterpéniques. On peut donc s'attendre à ce que certaines propriétés biologiques dues à ces composés (activités antibactérienne, antifongique, etc) restent les mêmes quelle que 
soit la saison. La race d'abeille semble aussi avoir une certaine influence sur la composition quantitative de la propolis. Les données obtenues fournissent des informations utiles sur l'origine botanique des échantillons étudiés. Les deux races d'abeilles récoltent évidemment la propolis sur un même ensemble de plantes mais, selon leur race, elles en privilégient certaines à certaines saisons. D'après nos résultats et les données bibliographiques sur les plantes tropicales, nous pourrions citer quelques plantes comme sources vraisemblables de propolis pour les échantillons étudiés ( $\mathrm{Bac}$ charis sp., Araucaria sp.), mais de plus amples recherches sont nécessaires pour connaître les plantes productrices de résine aux alentours des ruches. $\odot$ Inra/DIB/AGIB/Elsevier, Paris

Propolis / composition chimique / variation saisonnière / phénol / diterpène / Brésil / GC-MS

\section{Zusammenfassung - Jahreszeitliche Variation in der chemischen Zusam- mensetzung von brasilianischem Propo-} lis. In gemäßigten Zonen sammeln Bienen Propolis nur im Sommer. In Brasilien dagegen erfolgt die Sammlung während des ganzen Jahres. Wir untersuchten die jahreszeitlichen Änderungen in der Zusammensetzung von Propolis bei zwei Bienenrassen, der afrikanisierten Biene Apis mellifera und der europäischen Apis mellifera ligustica. Die Analysen erfolgten mit einem GC und einem GC-MS. Die Zusammensetzung des brasilianischen Propolis unterscheidet sich auf Grund seiner Herkunft von anderen Pflanzen signifikant vom europäischen Propolis. In den untersuchten Proben wurden als Hauptbestandteile Phenolderivate, meist Zimtsäurederivate, gefunden. Die einzige Ausnahme war eine Probe von Apis mellifera ligustica im Herbst, in der Diterpensäuren überwogen. Im Propolis beider Rassen traten im Sommer Diterpene auf, deren Anteil im Herbst ein Maximum erreichten. Diese waren während der anderen Jahreszeiten nicht nachzuweisen. Wie aus Tabelle $I$ hervorgeht, erfolgt gleichzeitig mit der Abnahme der Menge von einigen biologisch aktiven Komponenten, wie Phenolsäuren, eine Zunahme anderer biologisch aktiver Substanzen. Wir könnten demnach erwarten, daß auf Grund dieser bakteriziden, fungiziden etc. Verbindungen ein Teil der biologischen Aktivität während der verschiedenen Jahreszeiten weitgehend ähnlich erhalten bleibt. Auch die Bienenrasse schien einen gewissen Einflu $\beta$ auf die quantitative Zusammensetzung zu haben. Die Daten über die chemische Zusammensetzung des brasilianischen Propolis und die saisonalen Änderungen der Hauptbestandteile gaben nützliche Informationen über die pflanzliche Herkunft der Proben. Offensichtlich sammeln beide Rassen von den gleichen Pflanzen, aber je nach Rasse bevor7.ugen sie während bestimmter Jahreszeiten spezielle Arten. Auf der Basis dieser Ergebnisse und nach Literaturdaten über tropische Ptlanzen konnten wir einige Pflanzen angeben, die wahrscheinlich als Quelle der von uns untersuchten Proben dienten (Baccharis species, Araturaria species), aber weitere Untersuchungen über harzerzeugende Pflanzen in der Umgebung der Bienenstöcke sind notwendig. Inra/DIB/AGIB/Elsevier, Paris

\section{Propolis / Phenole / Diterpenes / GC-MS / Brasilien}

\section{REFERENCES}

[1] Aga H., Shibuya T., Sugimoto T.. Kurimoto M.. Nakajima Sh., Isolation and identification of antimicrobial compounds in Brazilian propolis, Biosci. Biolech. Biochem. 58 (1994) 945-946.

[2] Bankova V.. Dyulgerov A.. Popov S., Evstatieva L., Kuleva L.. Purcb O., Zamjanzan Z., Propolis in Bulgaria and Mongolia: phenolic compounds and plant origin, Apidologie 23 (1992) 79-85.

[3] Bankova V., Nikolova N., Marcucci M.C., A new lignan in Brazilian propolis, Z. Naturforsch. $5 \mathrm{lb}$ (1996) 7.35-7.37.

[4] Bankova V., Marcucci M.C.. Simova S., Nikoloval N., Popov S.. Antibacterial diterpenic acids from Brazilian propolis. Z. Naturforsch. $5 \mathrm{lc}$ (1996) 277-280. 
[5] Boudorova-Krasteva G., Bankova V., Sforcin J.M.. Nikolova N., Popov S., Phenolics from Brazilian propolis, Z. Naturforsch. 52c (1997) 676-679.

[6] Ghisalberti E.L., Propolis: a review, Bee world 60 (1979) 59-84.

[7] Greenaway W., Scaysbrook T., Whatley F.R.S., The analysis of bud exudate of Populus $x$ curamericana. and propolis, by gas chromatography-mass spectrometry, Proc. R. Soc. Lond. B232 (1987) 249-272.

[8] Markham K.R., Mitchel K.A., Wilkins A.L., Daldy J.A., Lu Y., HPLC and GC-MS identilication of the major organic constituents in New Zealand propolis. Phytochemistry 42 (1996) $205-211$.
[9] Popravko S.A., Gurevich A.I., Kolosov M.N., [Flavonoid components of propolis], Chim. Prir. Soed. 5 (1969) 476-482 (in Russian).

[10] Tomas-Barberan F.E., Garcia-Viguera C., VitOlivier P., Ferreres F., Tomas-Lorente F., Phytochemical evidence for the botanical origin of tropical propolis from Venezuela, Phytochemistry 34 (1993) 191-196.

[11] Toth G. Propolis: medicine or fraud? Am. Bee J. 125 (1985) 337-338.

[12] Wollenweber E., Asakava Y., Schillo D., Lehmann U., Weigel H., A novel caffeic acid derivative and other constituents of Populus bud excretion and propolis, Z. Naturforsch. 42c (1987) $1030-1034$. 